\title{
Historical trajectory and resilience in an agro- extractive settlement project in the Lower Tocantins River, Pará, Brazil
}

\author{
Trajetória histórica e resiliência em um projeto de \\ assentamento agroextrativista no Baixo Rio Tocantins, \\ Pará, Brasil
}

Gerciene de Jesus Lobato Ribeiro ${ }^{a}$

Ima Célia Guimarães Vieirab

${ }^{a}$ Master's Degree in Environmental Sciences, PhD Student, Universidade Federal do Pará (UFPA), Museu Paraense Emílio Goeldi e Embrapa, Belém, PA, Brazil E-mail: gercienelobato@hotmail.com

${ }^{b}$ Phd in Ecology, Researcher, Museu Paraense Emílio Goeldi, PA, Brazil E-mail: ima@museu-goeldi.br

doi:10.18472/SustDeb.v12n2.2021.34091

Received: 14/09/2020

Accepted: 06/07/2021

ARTICLE - VARIA

\begin{abstract}
The São João Batista riverside community experienced a golden phase in the production of cachaça from sugar cane (Saccharum officinarum L.). It underwent a period of decay around 1975 and, in 2004, became an Agro-extractive Settlement Project (PAE), with an economic system based on the exploitation and commercialization of açaí (Euterpe oleracea Mart.). This study analyzes the resilience of PAE São João Batista, Abaetetuba, Pará, from the establishment of sugar cane mills to the transition of their economic system to the exploitation and commercialization of açaí. It was based on field research conducted with 141 riverside dwellers employing semi-structured interviews. The adaptive cycle was built up, from which resilience was analyzed. The growth of the açaí fruit market identifies the community's point of resilience. The sugar cane-açaí economic system transition enabled riparian populations to experience changes and to create conditions for reorganizing themselves as a settlement.
\end{abstract}

Keywords: Adaptation. Uses of biodiversity. Socioecological System. Abaetetuba.

\section{RESUMO}

A comunidade ribeirinha São João Batista vivenciou uma fase áurea da produção da cachaça de canade-açúcar (Saccharum officinarum L.). Tendo passado por um período de decadência por volta de 1975, veio a se tornar um Projeto de Assentamento Agroextrativista (PAE) em 2004, agora com seu sistema econômico baseado na exploração e comercialização do açaí (Euterpe oleracea Mart.). Este estudo analisa a resiliência da comunidade do PAE São João Batista, Abaetetuba, Pará, em função do estabelecimento de engenhos de cana-de-açúcar e a transição do sistema econômico para a exploração e comercialização do açaí. O estudo se baseou em pesquisa de campo com 141 ribeirinhos por meio de entrevistas semiestruturadas. Construiu-se o ciclo adaptativo, a partir do qual foi feita a 
análise de resiliência. $O$ crescimento do mercado do fruto de açaí assinalou o ponto de resiliência da comunidade. A transição cana-açaí efetivou a capacidade dos ribeirinhos de experimentar mudanças $e$ criar condições para se reorganizarem enquanto assentamento.

Palavras-chave: Adaptação. Usos da biodiversidade. Sistema Socioecológico. Abaetetuba.

\section{INTRODUCTION}

Amazonian socioecological landscapes were shaped by human action in different intensities, and the use and exploitation of their natural resources have led to a stage of conflicts and struggle involving various actors and interests (ATHAYDE et al., 2016). Among these actors are the traditional populations who socially reproduce their ways of life by interacting with the environment.

In the floodplains of the Amazon estuary, ribeirinhos ${ }^{1}$, or riparian communities, have established systems of utilizing natural resources that combine various subsistence activities based on family labour and use of low-impact technologies derived from traditional knowledge (FERREIRA, 2012; LIMA; POZZOBON, 2005). Concerns about recognition of territorial rights of traditional populations and sustainability of territories and production systems induce the creation of rural territories of agro-extractive identity, which culminated with the advent of Agro-extractive Settlement Projects (Brazilian acronym: PAEs) as units of conservation of sustainable use, fulfilling the demands of the environmental movement and the land claims of social movements (ARAÚJO et al., 2019).

To understand how communities are affected by and respond to disturbances, complex systems theory has been applied through the representation of socioecological systems (Brazilian acronym: SSE). In the Tocantins River, in the large area affected by the Tucuruí dam, Bentes et al. (2014) showed that some communities have been organizing themselves through fishing agreements, towards better living conditions. This indicates that the changes directly or indirectly associated with habitat destruction, climate changes and overexploitation of biodiversity (SILVA et al., 2020) have been hitting human groups that greatly depend on natural resources through their effects on socioecological systems (HE; SILLIMAN, 2019).

PAEs may be regarded as a model of socioecological system where the social system includes farmers, extractors and fishermen, and their respective modes of production, institutions, production chains, social processes and relationships. The ecological system is addressed in different scales, ranging from the several terrestrial and aquatic environments to the unit of species extracted from these settlements. The social and ecological systems interact with each other, resulting in an "agro-extractive system" within socioecological systems on a wide scale, such as the international market (of açaí, for instance), biomes, global climate, etc. (OSTROM, 2009).

Under such a perspective, there is the resilience approach, whose society-nature interface is regarded from the feedback relationships that characterize the SSE (LINDOSO, 2017). The resilience of a system is defined as the ability of that system in dealing with disturbances while maintaining its functions (FOLKER et al., 2004). In the Amazonian context, Buschbacher (2014) uses the word resilience as meaning "the ability to deal with uncertainties, changes and surprises through adaptation, learning and self-organization". Through the adaptive cycle (HOLLING; GUNDERSON, 2002), one can describe how change patterns and processes over time occur in systems.

In that context, a historical review of the access to land and the survival strategies of riparian communities concerning the effects of environmental events and their consequences as well as their ways to adapt to the capitalist market allow for an analysis of their socioecological resilience and the possibilities of long-term planning. Particularly for the traditional Amazonian populations, the ability of socioenvironmental systems to respond and adjust to their milieu demonstrate their role in the conservation of the Amazonian Forest vis-à-vis global environmental changes, for their power of mediation of political transformations in various scales and territories (FLEURY et al., 2019). 
This paper analyzes the trajectory and resilience of PAE São João Batista, in the municipality of Abaetetuba (State of Pará), based on some elements of socioecological systems and resilience approaches (HOLLING, 2001; WALKER et al., 2006). By considering the adaptive cycle as a heuristic model, this approach has been employed to explore the dynamics and change trajectories of SSEs since the establishment of sugar cane mills in 1930 and the transition of the economic system to the exploitation and commerce of açaí. Resilience trends were analyzed in the light of the dimensions of social, economic and environmental capitals (SALVIA; QUARANTA, 2015), taking into account the different phases of the adaptive cycle.

\section{MATERIAL \& METHODS}

\subsection{STUDY AREA}

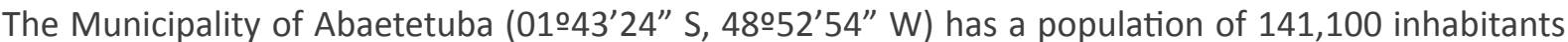
(IBGE, 2010) and its economy is mainly based on fishing, extractive gathering - foremost, of açaí) and agriculture (BARROS, 2009). Together with ten other municipalities, it constitutes the Lower Tocantins region, and its history is associated with the process of colonization of Amazonia, which is characterized by a model of economic integration with international capitalism (MACHADO, 2008).

From a socioenvironmental standpoint, Abaetetuba presents an expressive diversity punctuated with knowledge, memories, activities, symbologies, customs and a routine intertwined with the spaces of rivers, forests and floodplains (POJO; ELIAS, 2018). The municipality includes 72 islands that are geographically located in the lower course of the Tocantins River, at its confluence with the Pará River, in the estuary. The region is predominantly formed by floodplains and inhabited by riparian communities and quilombolas who are more or less intensely linked with the city, depending on their respective distance from urban centres (BARROS; SILVA, 2013).

For this study, we chose the island of Campompema (Figure 1), Pará, where the PAE São João Batista is located. The selection of this area is justified because it is one of the first localities where an Agro-extractive Settlement Project (PAE) was implemented in the Amazon, as part of the set of land recognition project models created in 2004 as a way to boost economic and environmental actions in floodplain areas historically occupied by traditional populations.

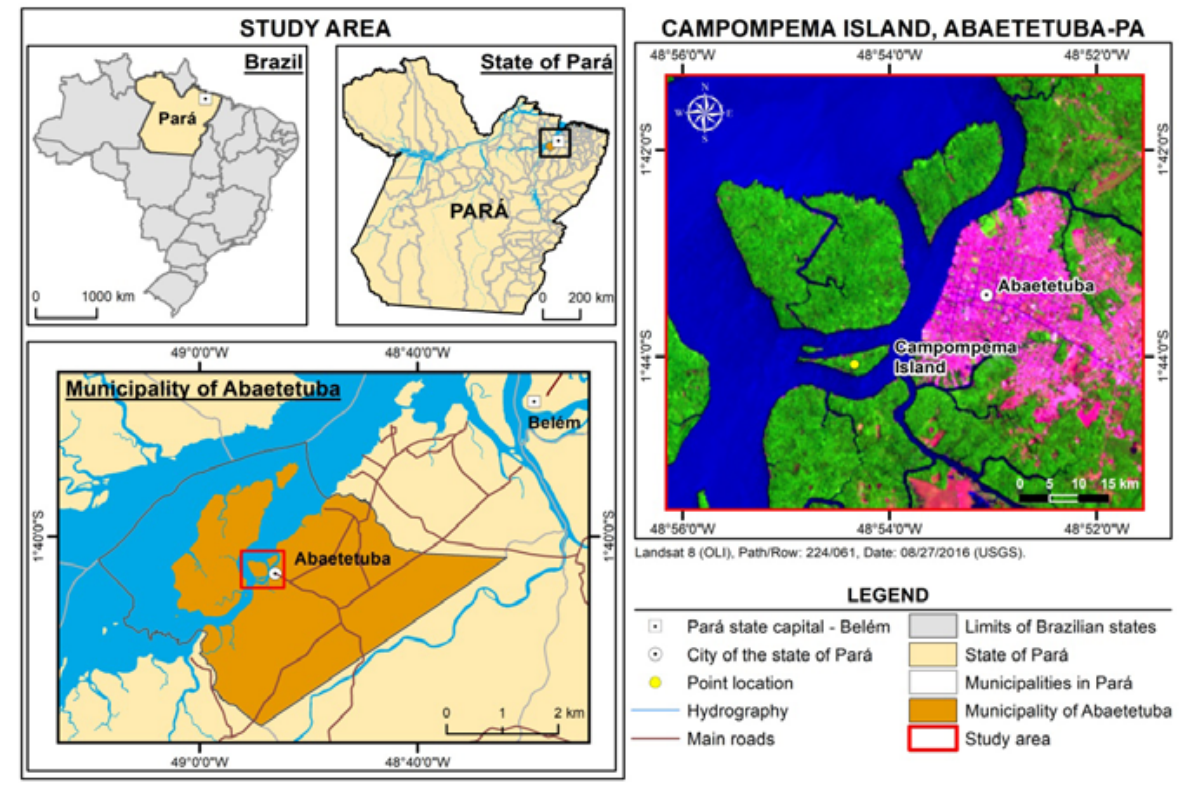

Figure 1 | Study area.

Source: Elaborated by the authors. 
PAE São João Batista was created through Ordinance Incra/SR (01)/№ 27 of 27 July 2004, published in the Diário Oficial da União [Official Gazette of the Union] № 146 of 30 July 2004, Section I, comprising an area of 471,961ha (INCRA, 2017). This settlement is the result of the struggles of local social movements to achieve land regularization. Initially, the riverside dwellers received the Sustainable Use Authorization Term issued by the Union Heritage Secretariat, this document being a facilitating element for access to government social benefits and effective for proving residence (IPEA, 2015). The riverside population of PAE São João Batista have developed survival strategies based on the use of natural resources, both related to fishing and extraction of forest products, to adapt to the political, social, environmental and economic changes. The São João Batista settlement experienced the golden phase of sugar cane cachaça (Saccharum officinarum L.) production in the 1960s; it had its moment of decay 15 years later, and in 2019, as a rural settlement, it starts to enjoy an economic system based mainly on the exploitation and commercialization of the açaí fruit (Euterpe oleracea Mart.), which has a global market.

\subsection{DATA COLLECTING}

To conduct this analytical-descriptive research meetings were initially held with the community leadership for exposure of the nature of the work and authorization of the research through the Written Informed Consent Form (WICF). Subsequently, the documents resulting from this previous moment were forwarded to Plataforma Brasil for evaluation. The Research Ethics Committee of the Health Sciences Institute of the Federal University of Pará (UFPA) approved its execution under CAAE 74844417.4.0000.0018.

The study included field research conducted from March to August 2018 in PAE São João Batista. The subjects involved in the research were the residents of the settlement area, totalling 141 interviewees (49\% of the population residing in the PAE). The age of the interviewees ranged from 18 to 59 years, with a higher percentage $(67 \%)$ of women.

Field research was conducted from March to August 2018 in the PAE São João Batista. The subjects involved in the research were the residents of the settlement area, totalling 141 interviewees (49\% of the population in the PAE). The age of the interviewees ranged from 18 to 59 years, with a higher percentage $(67 \%)$ of women.

Semi-structured interviews aimed at probing the population's way of life and identifying historical events and main factors influencing the trajectory of the establishment of the settlement. The interviews were carried out from $7 \mathrm{AM}$ to $5 \mathrm{PM}$ at the interviewees' residences, with a maximum of three interviews per day. As land ownership and access to natural resources in the São João Batista community are subjected to the rules of the Agro-extractive Settlement Project, the interviewers were aware that some questions could cause some discomfort due to concerns of financial or material loss. Therefore, interviewees were allowed to interrupt the questioning at any time, ensuring their autonomy and free will.

The interviewees' reports are referenced throughout the text with the initial letters of their name and age, guaranteeing the confidentiality of their identity. Subsequently, research was carried out in scientific literature (articles, books and institutional sites) to verify the political interventions in the settlement, in addition to historical records.

\subsection{ADAPTIVE CYCLE CONSTRUCTION}

Holling (2001) proposes a four-phase adaptive cycle model, where a system grows slowly (exploration phase), accumulates wealth for a sustained period (conservation phase), collapses (release phase), and rapidly reorganizes (reorganization phase), allowing it to grow in an identical or different configuration (HOLLING; GUNDERSON, 2002). 
The identification of the four phases of the adaptive cycle: $r$ - exploitation; $k$ - conservation; $\Omega$-release and $\alpha$ - reorganization was carried out based on the interviews and literature consultation, going through the adaptive cycles of sugar cane and in that of açai, from 1930 to 2018 . Thus, it would be possible to cover the reconstruction of the historical memory of local actors, even because this period marked the transition from sugarcane agriculture to the management of one of the most important species of Amazonian extractivism, which participates in the global market.

To describe the phases of the adaptive cycle, the assumptions detailed in Table 1 were considered, with the attribution of values referring to social, economic, and natural capitals, with 1 (one) for the criteria considered strong and 0 (zero) for those considered weak, according to Salvia and Quaranta (2015). Strong capital ensures a high level of resilience potential, as well as, conversely, weak capital signals an inability of the SSE to adapt, transform and respond overall to change, thus influencing the degree of resilience of the system. The criteria were identified by combining the components that would indicate whether the economic, social and natural capital would be well or poorly developed in the settlement.

Table 1 | Criteria for assessing resilience in the various phases of the adaptive cycle in the cultivation of sugar cane and açaí in PAE São João Batista, Abaetetuba, Pará.

\begin{tabular}{|c|c|c|c|c|}
\hline \multirow{2}{*}{ Phases (years) } & \multicolumn{3}{|c|}{ Capital } & \multirow{2}{*}{ Description } \\
\hline & Social & Economic & Natural & \\
\hline \multirow{2}{*}{$\begin{array}{c}\text { Exploitation (r) } \\
1930-1950\end{array}$} & $\begin{array}{l}\text { Presence of united } \\
\text { community, high } \\
\text { diversity (1) }\end{array}$ & $\begin{array}{l}\text { Riparian populations } \\
\text { with a wealth of } \\
\text { resources; high } \\
\text { commercialization } \\
\text { (1) }\end{array}$ & $\begin{array}{c}\text { Planting without } \\
\text { threatening local } \\
\text { biodiversity; species } \\
\text { such as açaí managed } \\
\text { for survival (1) }\end{array}$ & $\begin{array}{l}\text { Strongly developed } \\
\text { socioeconomic and } \\
\text { environmental capital } \\
\text { (1) }\end{array}$ \\
\hline & $\begin{array}{l}\text { Absence of united } \\
\text { community, low } \\
\text { diversity (0) }\end{array}$ & $\begin{array}{l}\text { Riparian populations } \\
\text { without a wealth } \\
\text { of resources, } \\
\text { highly dependent } \\
\text { on outside } \\
\text { financing; low } \\
\text { commercialization (0) }\end{array}$ & $\begin{array}{c}\text { Monoculture; } \\
\text { landscape } \\
\text { simplification; soil } \\
\text { degradation (0) }\end{array}$ & $\begin{array}{c}\text { Poorly developed } \\
\text { socioeconomic and } \\
\text { environmental capital } \\
(0)\end{array}$ \\
\hline \multirow{2}{*}{$\begin{array}{c}\text { Conservation (k) } \\
1960-1973\end{array}$} & $\begin{array}{l}\text { Good communication } \\
\text { between social } \\
\text { actors; investment } \\
\text { in infrastructure and } \\
\text { institutions for the } \\
\text { education of children } \\
\text { and youngsters (1) }\end{array}$ & $\begin{array}{l}\text { High productivity; } \\
\text { production flow; } \\
\text { generation of } \\
\text { employment and } \\
\text { income for } \\
\text { families (1) }\end{array}$ & $\begin{array}{l}\text { Low degradation } \\
\text { of forest and soil; } \\
\text { preservation of water } \\
\text { resources (1) }\end{array}$ & $\begin{array}{l}\text { Strongly developed } \\
\text { socioeconomic and } \\
\text { environmental } \\
\text { capital (1) }\end{array}$ \\
\hline & $\begin{array}{l}\text { Lack of } \\
\text { communication } \\
\text { between social } \\
\text { actors; lack of } \\
\text { investment in } \\
\text { infrastructure and } \\
\text { institutions for the } \\
\text { education of children } \\
\text { or youngsters }(0)\end{array}$ & $\begin{array}{l}\text { Low } \\
\text { commercialization } \\
\text { of resources; } \\
\text { difficulties in the } \\
\text { production flow and } \\
\text { the generation of } \\
\text { employment and } \\
\text { income (0) }\end{array}$ & $\begin{array}{l}\text { High degradation of } \\
\text { forest and soil; water } \\
\text { resources depleted } \\
(0)\end{array}$ & $\begin{array}{c}\text { Poorly developed } \\
\text { socioeconomic and } \\
\text { environmental capital } \\
(0)\end{array}$ \\
\hline
\end{tabular}




\begin{tabular}{|c|c|c|c|c|}
\hline \multirow{2}{*}{ Phases (years) } & \multicolumn{3}{|c|}{ Capital } & \multirow{2}{*}{ Description } \\
\hline & Social & Economic & Natural & \\
\hline \multirow{2}{*}{$\begin{array}{l}\text { Release }(\Omega) \\
1975-1987\end{array}$} & $\begin{array}{c}\text { High diversity; } \\
\text { incorporation } \\
\text { of traditional } \\
\text { techniques of } \\
\text { cultivation; support } \\
\text { for community social } \\
\text { programs (1) }\end{array}$ & $\begin{array}{c}\text { High product } \\
\text { commercialization (1) }\end{array}$ & $\begin{array}{l}\text { Low exploitation of } \\
\text { açaí (1) }\end{array}$ & $\begin{array}{l}\text { Strongly developed } \\
\text { socioeconomic and } \\
\text { environmental capital } \\
(1)\end{array}$ \\
\hline & $\begin{array}{c}\text { Low diversity; } \\
\text { technological } \\
\text { precariousness; } \\
\text { lack of support for } \\
\text { community social } \\
\text { programs; precarious } \\
\text { employment } \\
\text { situation; job } \\
\text { informality }(0)\end{array}$ & $\begin{array}{c}\text { Low product } \\
\text { commercialization (0) }\end{array}$ & $\begin{array}{c}\text { Sharply increased } \\
\text { process of açaí } \\
\text { exploitation (0) }\end{array}$ & $\begin{array}{l}\text { Poorly developed } \\
\text { socioeconomic and } \\
\text { environmental capital } \\
(0)\end{array}$ \\
\hline \multirow{2}{*}{$\begin{array}{l}\text { Re-organization }(\alpha) \\
1990-2004\end{array}$} & $\begin{array}{l}\text { The ability of the } \\
\text { organization in } \\
\text { networks and key } \\
\text { institutions such } \\
\text { as co-operatives, } \\
\text { associations; } \\
\text { the presence of } \\
\text { consulting services } \\
\text { for riparian } \\
\text { communities (1) }\end{array}$ & $\begin{array}{l}\text { The low requirement } \\
\text { to import resources } \\
\text { for community } \\
\text { survival; the } \\
\text { extractive gathering } \\
\text { of plants as a source } \\
\text { of income and job } \\
\text { assurance (1) }\end{array}$ & $\begin{array}{c}\text { Natural resources } \\
\text { available for } \\
\text { exploitation: good } \\
\text { water and soil quality } \\
\text { (1) }\end{array}$ & $\begin{array}{l}\text { Strongly developed } \\
\text { socioeconomic and } \\
\text { environmental capital } \\
\text { (1) }\end{array}$ \\
\hline & $\begin{array}{l}\text { The inability of } \\
\text { organization in } \\
\text { networks and key } \\
\text { institutions such } \\
\text { as co-operatives, } \\
\text { associations; absence } \\
\text { of consulting } \\
\text { services for riparian } \\
\text { communities (0) }\end{array}$ & $\begin{array}{c}\text { The high requirement } \\
\text { to import resources } \\
\text { for community } \\
\text { survival }(0)\end{array}$ & $\begin{array}{c}\text { Natural resources } \\
\text { unavailable for } \\
\text { exploitation: poor } \\
\text { water and soil quality } \\
\text { (0) }\end{array}$ & $\begin{array}{l}\text { Poorly developed } \\
\text { socioeconomic and } \\
\text { environmental capital } \\
(0)\end{array}$ \\
\hline \multirow{2}{*}{$\begin{array}{l}\text { Exploitation (r) } \\
2007 \text { - Current }\end{array}$} & $\begin{array}{l}\text { Social mobilization: } \\
\text { the presence } \\
\text { of schools and } \\
\text { services for riparian } \\
\text { communities; } \\
\text { social integration of } \\
\text { families (1) }\end{array}$ & $\begin{array}{l}\text { High resource } \\
\text { commercialization; } \\
\text { participation in } \\
\text { programs of financial } \\
\text { support; acceptance } \\
\text { in markets (1) }\end{array}$ & $\begin{array}{l}\text { Good soil and water } \\
\text { quality; preservation } \\
\text { of local biodiversity } \\
\text { (1) }\end{array}$ & $\begin{array}{c}\text { Strongly developed } \\
\text { socioeconomic and } \\
\text { environmental capital } \\
(1)\end{array}$ \\
\hline & $\begin{array}{l}\text { Absence of social } \\
\text { organization; lack } \\
\text { of schools and } \\
\text { services for riparian } \\
\text { communities (0) }\end{array}$ & $\begin{array}{c}\text { Low resource } \\
\text { commercialization; } \\
\text { lack of participation in } \\
\text { programs of financial } \\
\text { support; rejection in } \\
\text { markets }(0)\end{array}$ & $\begin{array}{l}\text { Monoculture; soil } \\
\text { degradation; poor } \\
\text { water quality; } \\
\text { local biodiversity } \\
\text { threatened (0) }\end{array}$ & $\begin{array}{l}\text { Poorly developed } \\
\text { socioeconomic and } \\
\text { environmental capital } \\
(0)\end{array}$ \\
\hline
\end{tabular}

Source: Elaborated by the authors.

Changes in the PAE were analyzed in light of the dynamics that shaped the social, economic, and natural capitals described in Table 1 . The analysis of resilience trends, extrapolated from the trajectories of the three different types of capitals, led to the construction of the adaptive cycle from 1930 to 2018 for the sugar cane cultivation and açaí production sectors. Based on the criteria presented in Table 1 and, subsequently, based on the levels attributed to the capital (strong or weak), we obtained the valuation and indication of resilience in each phase of the adaptive cycle as Not Resilient $=0$; Slightly Resilient $=$ 1-2 and Resilient $=3$. The resilience indicators incorporate the different phases of the adaptive cycle and can act as a barometer of overall resilience, because their presence suggests a resilient SSE, while their absence or disappearance suggests a loss of resilience and greater vulnerability to disturbances (CABELL; OELOFSE, 2012). The flowchart of the research with its steps is presented in Figure 2. 


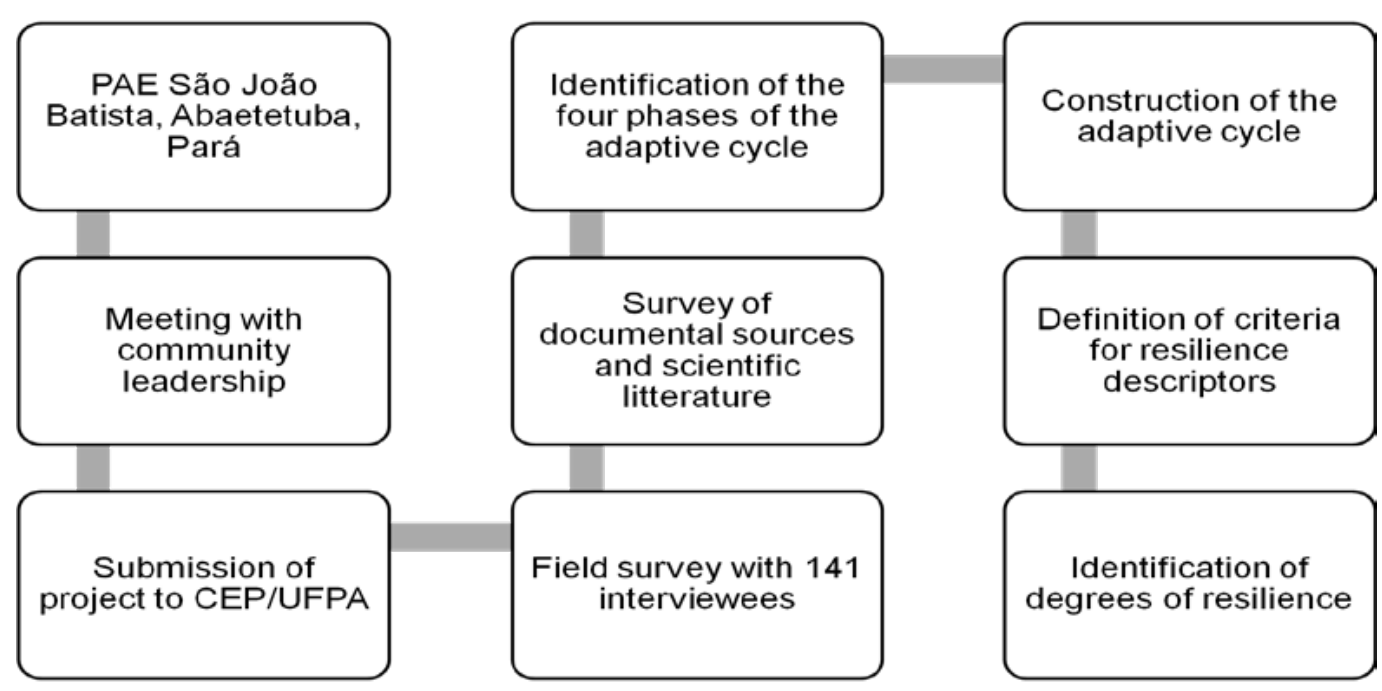

Figure 2 | Flowchart of the study in the PAE São João Batista, Abaetetuba, Pará.

\section{RESULTS AND DISCUSSION}

Along their historical trajectories (Figure 3), sugarcane and açaí were necessary resources for the socioeconomic reproduction of the riparian communities in the PAE São João Batista, because it was through them that the process of territorial occupation and exploitation of natural resources took place, as well as changes in land use.

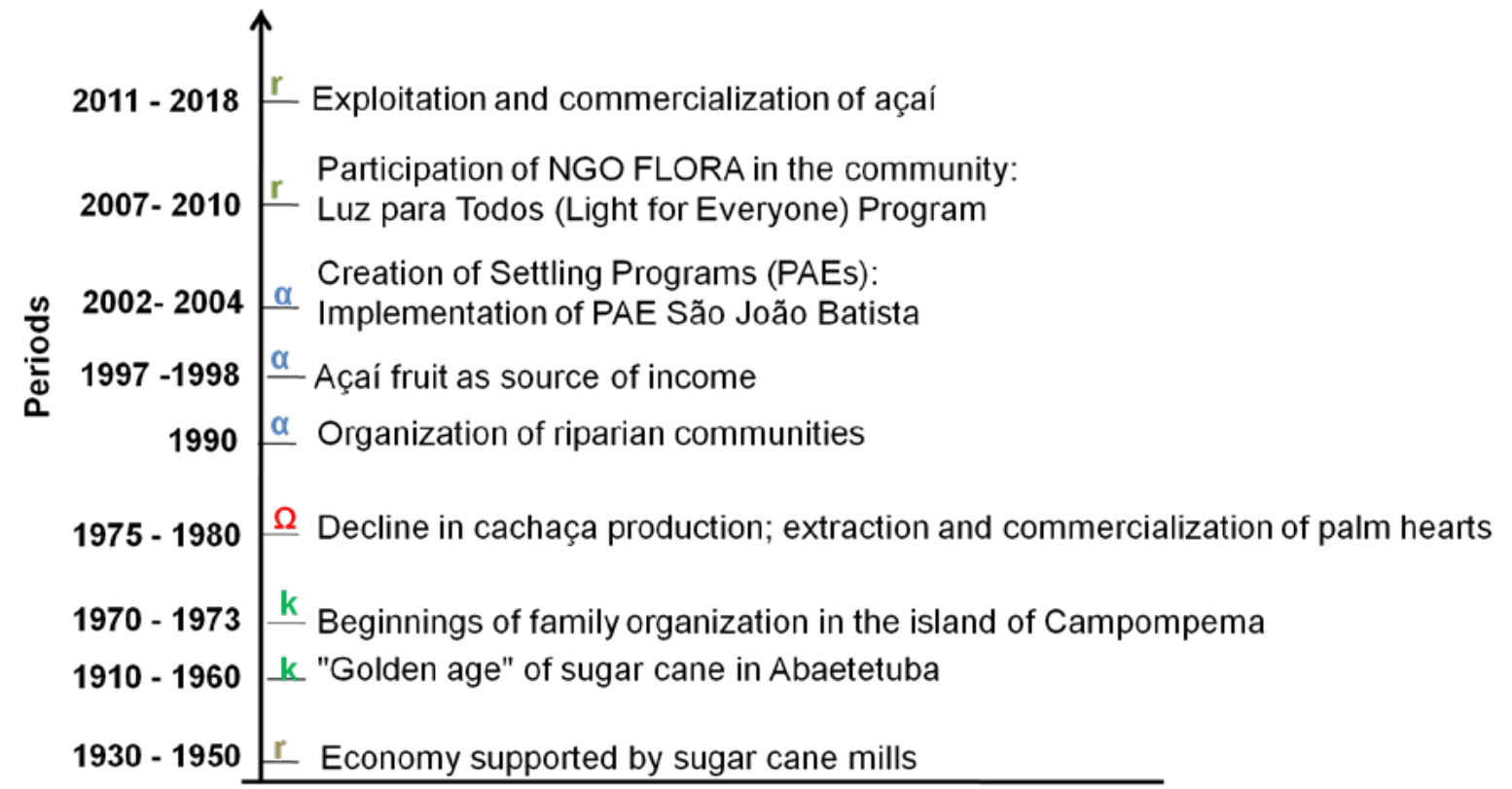

\section{Events}

Figure 3 | Historical trajectory of the PAE São João Batista territory, based on the cultivation of sugar cane and açaí respectively. 


\subsection{PHASES OF THE ADAPTIVE CYCLES IN THE PAE SÃO JOÃO BATISTA}

\subsubsection{SUGAR CANE - EXPLOITATION $(r)$}

In 1930 the riparian dwellers from the island of Campompema worked in the Santa Cruz sugar cane mill. It belonged to Mr Murilo Parente Carvalho, located next to the Abaeté River, which remained in operation until around the 1960s and controlled the economic, social and environmental aspects of their lives, described as follows: "The Santa Cruz mill produced lots of cachaça and its profits supported our life here in the community (B. L. S., 83 yo.). "There were no açaí sales, they sold cachaça" (R. N., 74 yo.).

Sugar cane sticks were cut in pieces of about $80 \mathrm{~cm}$ in length and piled up in the field in bundles that were carried and tied up in lots of ten, forming a frasqueira of cane (ANDERSON, 1991). Frasqueira was a unit agreed between the sugar cane collector and the mill owner for commercial transactions. In many cases, this agreement occurred in the form of a deal by which the mill owner would offer the land and the worker with his labour (NAHUM, 2011). The cane collector would get some financing from the mill owner to prepare the land, plant the cane, keep it in condition and then cut down the yield.

In exchange for an aviamento $^{2}$ of a sugar cane plot (done with consumption goods available at the mill's store), the mill owner expected the cane collector to deliver his entire production. It was a person-toperson, informal arrangement that benefited only one-tenth of the farmers, and the workers without resources or aviamento were forced to become daily labourers (ANDERSON, 1991).

\subsubsection{SUGAR CANE - CONSERVATION (K)}

Together with other family mills, the Santa Cruz mill ensured the floodplain area population a stable income (ROGEZ, 2000), particularly in the 1960s, when the sugar cane yield had its "golden phase" in Abaetetuba. The increase in demand led to the installation of the first steam machines destined exclusively for the production of spirits (cachaça), whose quality was acclaimed all over the Pará State (MACHADO, 2008). However, the mills always operated following a primitive conception of production and economic relations and, over time, these means of survival declined.

In the 1970s, many workers resorted to the judicial system to claim their rights from the mill owners, and to avoid a larger social conflict, the State demanded the owners give away part of their lands in allotments to redress workers compensations (QUARESMA et al., 2015).

\subsubsection{SUGAR CANE - RELEASE $(\Omega)$}

Planting and commercialization of sugarcane started to decline in 1975, as "it was slave work, l earned three thousand réis [three cruzeiros] a week, then Labor Justice came and closed down the mill" (R. N., 74 yo.). For some, "life in the mill was tiresome, only the owner had profits" (J. M., 56 yo.). Indeed, intensive labour was predominant in the mills, and cachaça production underwent a crisis; workers were not paid government incentives and were harmed the worst (QUARESMA et al., 2015). Furthermore, the precarious conditions of the mills, the refusal to replace the aviamento system with more modern practices, technological unreliability and the introduction of new labour laws all contributed to the overall deterioration (MACHADO, 2008; NAHUM, 2011). 
The activities in the mills declined, "each of us began taking care of our plot" (J. M., 56 yo.), and as some ribeirinhos would not accept the current situation and demanded improvements, between 1970 and 1973 meetings began to happen involving representatives of the Catholic Church to discuss family organization in Campompema island. "Four residents were helped by the Diocese to create the community, they organized their families to be registered and be recognized (B.L.S., 83 yo.), so the São João Batista Community was created. The role of the Church was determinant in this process of territorialization of riparian communities, as it developed theoretical and practical political constructions to raise consciousness for the real situations that unleash oppression (GONÇALVES et al., 2019).

The creation of the community coincided with the period of decline of the sugar cane production, a period in which the slowdown in the production of "cachaça" led the system to collapse, so the workers that depended on it were forced to look for alternative ways to survive, as "There was nothing, it was a situation of dereliction" (J. M., 56 yo.). Traditional food resources were exploited with increasing intensity: hunting became practically extinct, fishing did not bring much income; shrimp, which was a dietary complement, became subjected to predatory capture for resale; and whole açaí groves were cut down to sell the heart of palm to factories located in the estuary (ANDERSON, 1991). Indeed, the destruction of the varzea forests with acai palms was so intense that state intervention was necessary through Law $n^{\circ} 6.576 / 1978$, which banned the felling of açaí palm trees in the entire Brazilian territory - to little avail, as in 1980 the State of Pará became the main extractor and producer of canned hearts of palm in Brazil (MOURÃO, 2010).

\subsubsection{RE-ORGANIZATION $(\alpha)$}

Intense exploitation of açai forests was associated with the informality of the occupation, like the federal administration of the territory allowed riparian communities to become vulnerable to third-party activities (ALVES, 2016). However, from 1990 on the Land Pastoral Commission (Brazilian acronym: CPT), the Basic Ecclesial Communities (Brazilian acronym: CEBs), the Union of Rural Workers (Brazilian acronym: STTRs), the Fishermen's Colony and local associations got together to organize riparian communities towards recognition, demarcation and land titling (GONÇALVES et al., 2016).

Simultaneously to that process of organization, the production pattern of açaí would be altered from extractive to cultivated and/or directed management (FERREIRA, 2012). The growth of the açaí fruit market in the 1990 s caused a positive effect on its preservation and conservation (TAVARES; HOMMA, 2015). In 1997 and 1998, that fruit was an important source of income, especially due to the increasing demand in markets beyond the region, which ended up favouring the Rural Settlement Projects (Brazilian acronym, PAs) in the islands around Abaetetuba in 2002 (FERREIRA, 2012; GONÇALVES et al., 2016).

The Agroextractive Settlement Projects (PAEs) anticipated the exploitation of areas provided with extractive riches through economically feasible, socially fair and ecologically sustainable activities in the Amazonian floodplains. In 2002-2004, populations that occupied or intended to occupy these areas would implement those activities (BRASIL, 1996). PAE São João Batista was implemented in 2004 in the island of Campompema, and one of its goals was to foster the productive chain of the exploited natural resources (ALVES, 2016). 


\subsubsection{AÇAÍ- EXPLOITATION (r)}

During the exploitation and commercialization of sugar cane spirits (cachaça), açaí production was geared toward family survival: açaí fruit was collected and vines were cut off to ease its handpicking. The natural abundance of açaí palms was little affected by humans, to whom they supplied enough for their domestic needs, and management was restricted to backyard clumps where the fruit was collected (MARINHO, 2009). This state of affairs, however, began to change with the progressive market demand for açaí, which favoured the implementation of the PAE São João Batista in Campompema Island. According to locals, in 2007 and 2008 the non-governmental organization FLORA created a module of permanent planting of açaí palm for the riparian community to strengthen forest conservation. In 2010 Campompema island was included in the Program Luz para Todos (LpT-Light for All), created by the federal government (Decree 4.873/2003) to increase income and promoting the social inclusion of benefitted communities by providing access to electricity (FREITAS; SILVEIRA, 2015). This program brought an electric energy to 41 residences (among the interviewees) who managed to register in the PAE São João Batista. Others who missed their registration live on energy regularly supplied by Centrais Elétricas do Pará (Celpa). There are also small private energy suppliers, altogether summing up 100 families who can enjoy electrical energy.

The settlement also harbours the actions of institutions such as the Movement for the Ribeirinhos and Ribeirinhas of the Abaetetuba Floodplains (Brazilian acronym: Moriva), the Movement for the Ribeirinhos and Ribeirinhas of the Settlement Projects (Brazilian acronym: Moripa), churches, the PAE São João Batista Association. More recently the Abaetetuba Town Hall implemented a system of water supply and distribution to the residents that helped the exploitation and commercialization of açai fruit in local and external markets. It is estimated that açaí is the main source of income for $77 \%$ of the rural population in northeastern Pará (SANTANA et al., 2012).

Likewise, the riparian community of the São João settlement have açaí as their basic source of income, which explains their appropriation of floodplain areas for management of açaí palm trees: it was found to be so in $75 \%$ of the analyzes family establishments. Management of floodplain forests for açaí production is done off-season (from January to July) and involves the felling of the tallest and least productive palm trees, cleaning the plot and then its enrichment with the planting of new açai palm trees. During this off-season period, the source of income for the locals is the selling of artefacts, fish and shrimp in local marketplaces and also official government money transfer programs such as Bolsa Família ${ }^{3}$.

The commercialization of açaí fruit is done in local marketplaces or through the Abaetetuba Fruit Farmers Co-operative (Brazilian acronym: Cofruta), created in March 2002, in which eight ribeirinhos of the settlement take part (an informant). Besides Cofruta, through the agro-extraction of açaí, the riparian communities aim to strengthen their production chain through access to microcredit and business advice. Thirteen per cent of ribeirinhos requested support from the Amazônia Florescer program (Amazonia Blossoming) of the Banco da Amazônia, so that a family could have resources to enhance the development of their extractive activities: for instance, $7 \%$ of the families were consolidating a partnership with the company " $100 \%$ Amazônia" to be able to sell açaí at its best price.

\subsection{ADAPTIVE CYCLE AND RESILIENCE OF THE PAE SÃO JOÃO BATISTA}

The historical process of occupation of the PAE is associated with the community's ways of life in interaction with the floodplain environment and the production of sugar cane and açai palm. The importance of the historical trajectory is shown in the adaptive cycle about these cultivations (Figure 4). 


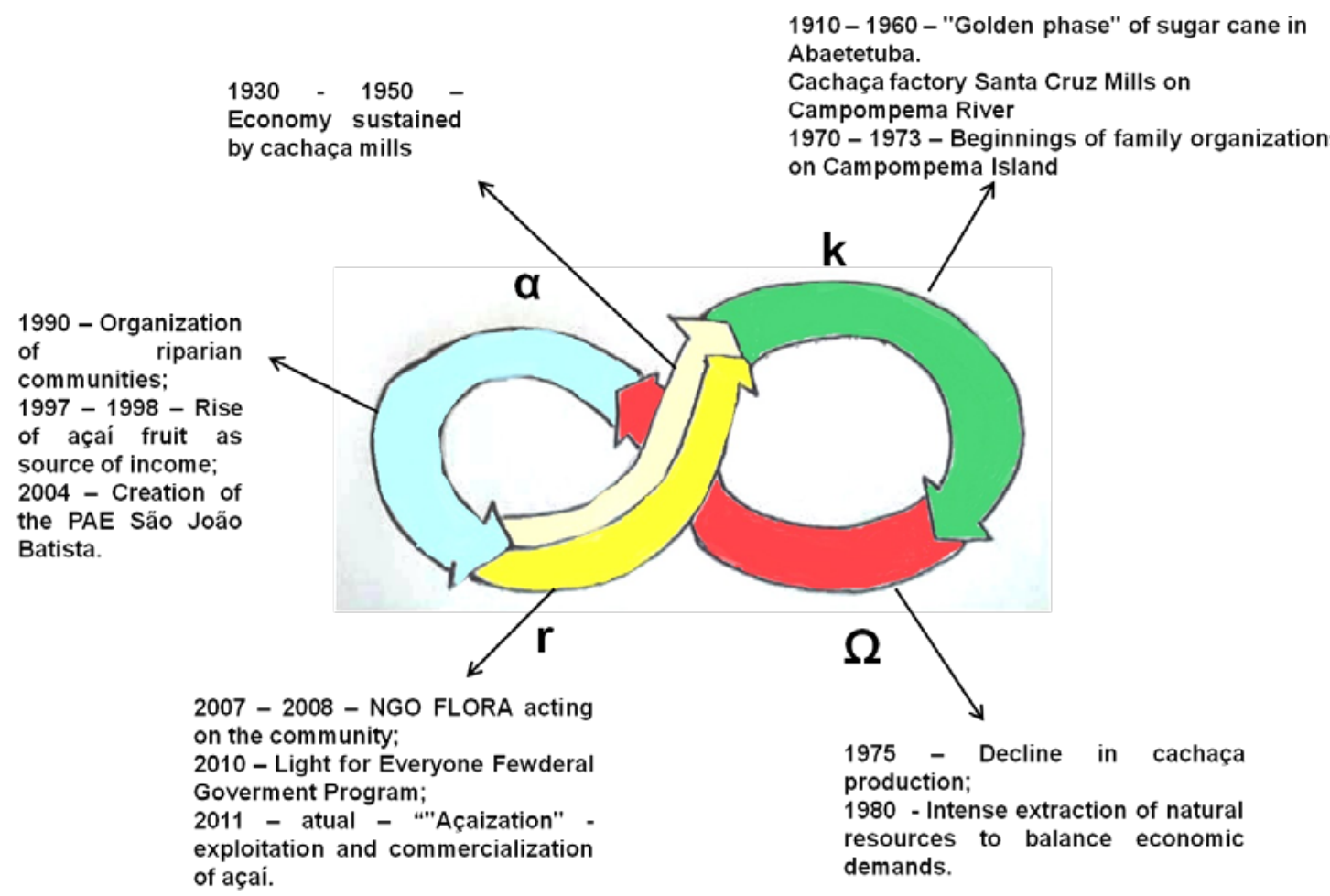

Figure 4 | Adaptive cycle with the historical trajectory of the PAE São João Batista, about the cultivation of sugar cane and açaí respectively. Phases: $r$ - exploitation; $k$ - conservation; $\Omega$ - release and $\alpha$--re-organization.

Table 2 shows the evaluation of social, economic and natural capitals and their respective association with socioecological resilience.

Table 2 | Evaluation of resilience in each phase of the adaptive cycle in the PAE São João Batista, Abaetetuba, Pará.

\begin{tabular}{ccccccc}
\hline Phases & $\begin{array}{c}\text { Social } \\
\text { Capital }\end{array}$ & Economic Capital & $\begin{array}{c}\text { Natural } \\
\text { Capital }\end{array}$ & Value & Resilience & Land use \\
\hline Exploitation $(\mathrm{r})$ & Strong 1 & Strong 1 & Strong 1 & 3 & Resilient & Sugar cane \\
Conservation $(\mathrm{k})$ & Weak 0 & Strong 1 & Weak 0 & 1 & Slightly Resilient & Sugar cane \\
Release $(\Omega)$ & Weak 0 & Weak 0 & Weak 0 & 0 & Non-Resilient & Sugar cane \\
Re-organization $(\alpha)$ & Strong 1 & Strong 1 & Strong 1 & 3 & Resilient & Açaí \\
Exploitation $(\mathrm{r})$ & Strong 1 & Strong 1 & Weak 0 & 2 & Slightly Resilient & Açaí \\
\hline & & Source: Elaborated by the authors. & &
\end{tabular}

Sugar cane cultivation in this riparian community in 1930, in the exploitation phase (r), structured a production system around the mill, with intensive labour, an abundance of natural resources and a high degree of commercialization. Although dealing with a monoculture, that phase was considered "Resilient". With that cultivation, its potential (the possibility of system transformation) increased together with the growth of interrelationships, following into phase k. The latter was characterized by the economic prosperity caused by sugar cane and the unleashing of disturbances resulting from labour laws, competition with other markets and participation of ribeirinhos in social movements, culminating in the organization of the community. The economical capital in phase $\mathrm{k}$ is positive, but social and environmental capitals were negative; hence, this phase was considered "Slightly Resilient."

Agents of change led to the collapse of the system (phase $\Omega$ ), and the extraction of açai palm hearts represented a reaction against sudden changes and created conditions for innovation. In this phase, all aspects are problematic, so it can be labelled "Non-Resilient". 
The sugar cane cycle ends up reorganizing itself (phase $\alpha$ ) taking advantage of opportunities such as the recognition and territorial demarcation of riparian communities like the PAE São João Batista, and the rise of açaí. Ribeirinhos showed an ability to organize themselves using plant extraction as a source of income, employment and social integration; therefore, it could be said that the phase of re-organization and current exploitation is "Resilient".

The cycle starts all over (phase $r$ ), now with an economic foundation in açaí management and social and economic capitals both considered strongly developed. However, the natural capital is weak, as that cultivation is a monoculture and has caused soil degradation, poor water quality and a threat to local biodiversity, thus characterizing a phase of "Slight Resilience".

On the other hand, the ribeirinhos are still dependent on a whole set of activities, such as the cultivation of medicinal species, particularly peppermint (Mentha sp.); catching fish and shrimp in rivers and streams, and handicraft making (Figure 5). This allows for new forms of adaptation and has led to a good level of resilience of the socioecological system, considering the number of changes they underwent. Furthermore, as the communities organized themselves into a form of settlement that attracted public policies and official support for production, we can acknowledge that settlement as "Resilient".

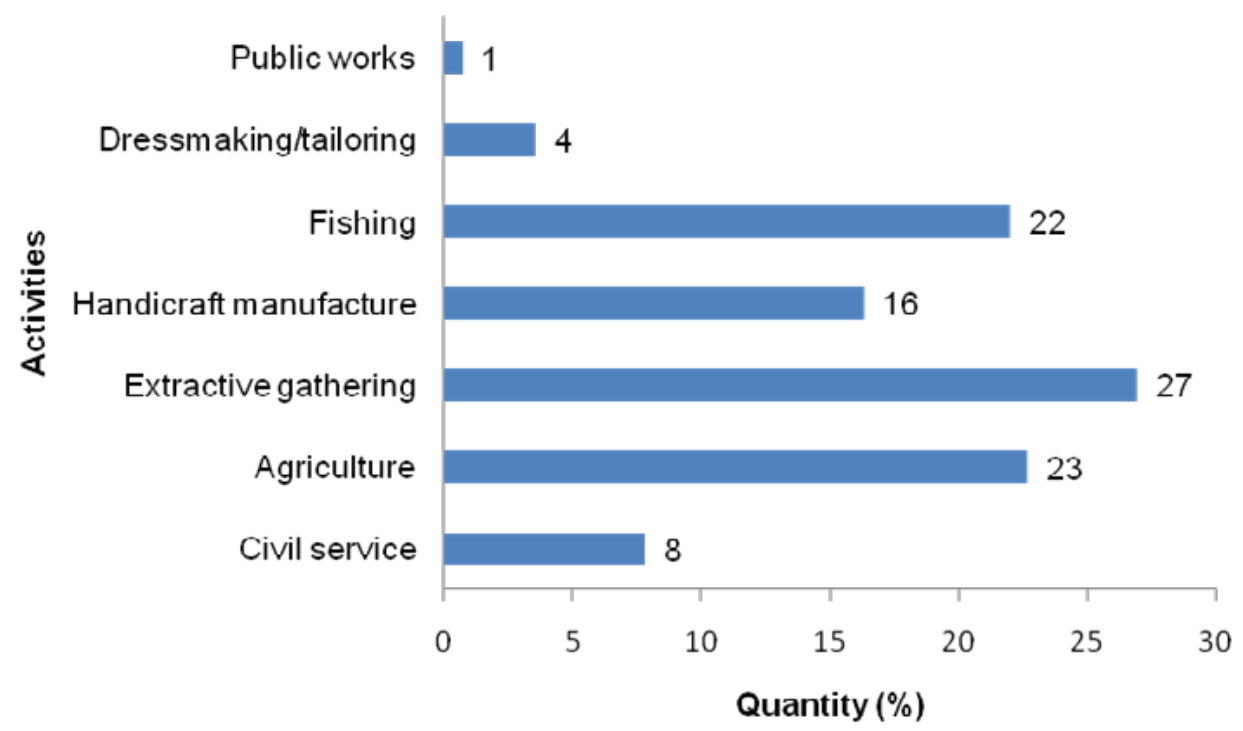

Figure 5 | Activities took by the riparian communities in the São João Batista settlement, Abaetetuba, Pará.

From a social standpoint, most of the community members remained in the settlement and adopted the extractive gathering of açai fruit as their main activity, one that is expanding in the municipality and showed resilience to changes. Settlement policies, land reform and integration programs (such as Bolsa Familia) indeed provided the necessary security in the period of disturbances in the SSE. Ecologically, although considered a low-impact activity, the exploitation of açaí changed to fulfil the increase in demand and, therefore, exerted pressure on floodplain forests and incurred an impact on biodiversity and the provision of ecosystem services.

The expansion of açaí planting to cram the floodplain forest areas where it already occurs naturally was regarded as a new way of development in the PAE São João Batista. Açaí is an important species for subsistence, for family income and to ensure land occupation, and signals the point of resilience in the community, which kept its structure and adopted the exploitation and commercialization of the fruit for self-organizing (phase $\alpha$ of the adaptive cycle). There was a potential for an unexpected and quick change that resulted in a process of positive feedback, maintaining its identity (BUSCHBACHER et al., 2016). However, the environmental consequences of these changes have altered local biodiversity and landscape (GONÇALVES; BRASIL, 2016), due to the current extractive model practised by riparian communities in the Amazon estuary (FREITAS et al., 2015). 


\section{3 "AÇAIZATION" AND THE FUTURE OF THE PAE}

Increasing commercial demand for açaí fruit in Brazil and abroad made it the main source of income for the riparian communities in the Amazonian estuary. However, to survive in this ever-shifting market, agroextractivists intensified the management of açai in the varzea forests. Such practices in the estuarine floodplain involve thinning of sprouts and cutting of trees around the clumps of açaizais to allow more access to light and make the plant more competitive and transplanting seedlings from those clumps into areas of spontaneous occurrence of açaí to constitute homogenous formations of the plant (TAGORE, 2017). This type of management leaves the environment subjected to threats that could affect its ecological system, especially when açaí becomes the dominant species in the settlement (Figure 6), a fact referred to by Hiraoka (1993) as "açaization".

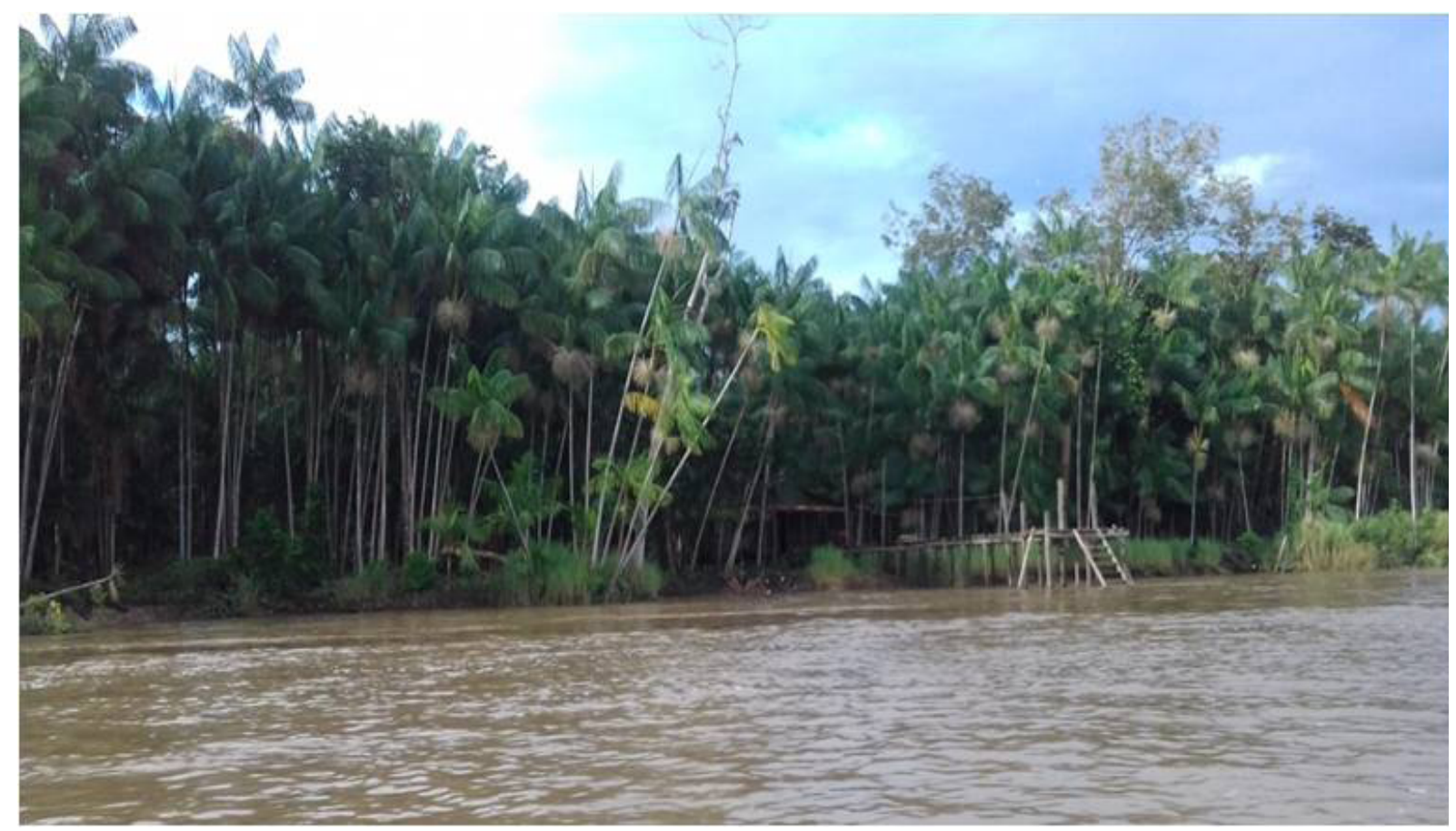

Figure 6 | Expressive presence of açaí (Euterpe oleracea Mart.) in the landscape of the PAE São João Batista,

Campompema island, Abaetetuba, Pará.

Source: Elaborated by the authors.

The negative consequences of the intensive management of açaí in the PAE São João Batista have already begun to be perceived by the ribeirinhos, as statements such as the following often appeared in the interviews: "The soil started to crumble because of felling the trees." (N. C. N., 32 yo.). "The land is lowering, tree roots are too much up there, so the tree loses its leaves, too much deforestation" (A. S. S. N., 64 yo.); "Açaí dries up in the tree because there is pollution, deforestation" (R. S. N., 74 yo.); "Açaí is hanging on up there, drying up, then it falls" (J. M., 56 yo.); "Animals are vanishing because they are killing the trees" (M. S. A. F., 55 yo.).

In the 1990s, the production of native açaí fruit that was due almost exclusively to extractive gathering began to include also those taken from managed and cultivated native açaí trees (NOGUEIRA et al., 1995). The possibility of expanding the profitability of açai production employing management by increasing palm densities in floodplains improved the income of families and kept the forest standing. Indeed, the goal of managing acai palm trees is to generate economic, ecological and social benefits to traditional communities (JARDIM, 2002): therefore, various techniques are employed to increase production and boost consumption and commerce (SANTOS JÚNIOR et al., 2015). 
The expanding demand for açaí fruit has transformed a vast portion of the diverse riverine forest into a quasi-monodominant açaí forest and the changes were perceived by the ribeirinhos as they expressed in the interviews. Intensification of management and exploitation of açaí has resulted in the loss of over $50 \%$ of the diversity of tree species and a reduction of $63 \%$ in the number of pioneer species of the varzea forests (FREITAS et al., 2015). Removal of tree species from the floodplain often leads to poor yield and quality of açaí fruit, as the açaí palm tree is strongly dependent on ecosystem services such as pollination: according to Campbell et al. (2017), the presence of bees, in particular, is larger in floodplain areas surrounded by dense vegetative cover.

Still, on the suppression of the native vegetation, the interviews evidenced deforestation in river margins due to the extinction of the riparian forest, causing deposition of sediment in rivers. Gonçalves and Brasil (2016) and Tagore et al. (2018) also pointed at that environmental problem and emphasized that the fall of native trees weakens the cliff sides and river banks, and therefore the erosion and deposition of large amounts of sediments in the river beds.

The environmental threats to the estuary floodplains previously described were driven by a public policy based on the use of natural resources. Even if the ribeirinhos improved the infrastructure of their residences and boats with the implementation of the PAE with the financing that allowed the expansion of the açaí market, they faced new challenges with the preservation of the Amazonian estuary floodplain.

\section{CONCLUSION}

The history and the resilience of the community in the PAE São João Batista, Campompema island, Abaetetuba, Pará, are set in a given scale where the adaptive cycle reveals that the change (or disturbance) of the system occurred due to the decline in sugar cane yield. The transition of the economic system Sugar Cane-Açaí elicited the ability of the ribeirinhos to experiment with changes and created conditions for their re-organization as a settlement.

The phases of the adaptive cycle of exploitation and growth, anchored in the use and commercialization of açaí allowed by the settlement, classify the latter as "Resilient". However, it is important to highlight the role of local institutions, public policies and the ribeirinhos in strengthening that resilience, as the challenge is to make them able to face periods of instability, taking advantage of the opportunities brought in by their productive activities such as fishing and the cultivation of other plant species, handicraft-making and cultural diversity.

In the current picture of increased pressure on floodplain forests for the production of açaí, collective actions must be worked on to better articulate their yield and commercialization and to create new socioecological relationships. That would ensure conservation and maintenance of environmental services in the floodplain forest, and the permanence and sustainability of riparian communities who live on the extractive gathering of açaí in their lands.

The adaptive cycle can be considered a heuristic model which, combined with resilience analysis, constitutes a useful tool to study the trajectory of socioecological systems in Amazonia and to identify possible determining factors of their changes and reorganizations. This would propitiate opportunities for planning in a context of quick and profound changes in the Anthropocene. 


\section{NOTES}

${ }^{1}$ This paper follows Lira and Chaves (2016) and equally employs the words "riparian communities" and "ribeirinhos" to designate the residents of the PAE São João Batista, which is only accessible by inland waterway and whose way of life is identified by their use of forest and water resources.

\footnotetext{
${ }^{2}$ Aviamento was a system of credit focused on a commercial establishment that attached to the mill, where a primitive form of bookkeeping registered on a notebook the mill workers' withdrawals and their yield. At the end of the month, the withdrawals were discounted from the salary previously settled with the mill owner (MACHADO, 2008).

${ }^{3}$ Bolsa Familia (Family Endowment) is a federal program of conditional transference of a stipend destined to poor families who meet certain conditions related to health and education (SILVA; PAES, 2019).
}

\section{REFERENCES}

ALVES, F. (Org.). A função socioambiental do patrimônio da União na Amazônia. Brasília: Ipea, 2016.

ANDERSON, S. D. Engenhos na várzea: uma análise do declínio de um sistema de produção tradicional na Amazônia. In: LENA, P.; OLIVEIRA, A. E. de. Amazônia: a fronteira 20 anos depois. CEJUP, Belém. 1991.

ARAÚJO, R. et al. Territórios e alianças políticas do pós-ambientalismo. Estudos Avançados, v. 33, n. 95, p. 67-90, 2019.

ATHAYDE, S. et al. Avaliação da resiliência socioecológica como ferramenta para a gestão da fronteira amazônica: experiências e reflexões. Sustentabilidade em Debate, v. 7, n. 2, p. 14-19, 2016.

BARROS, F. B. Sociabilidade, cultura e biodiversidade na beira de Abaetetuba no Pará. Ciências Sociais Unisinos, v. 45, n. 2, p. 152-161, 2009.

BARROS, F. B.; SILVA, D. Da. Os mingauleiros de miriti: trabalho, sociabilidade e consumo na beira de Abaetetuba, Pará. Revista FSA (Centro Universitário Santo Agostinho), v. 10, n. 4, p. 44-66, 2013.

BENTES, E. dos S. et al. A pesca artesanal a jusante da Usina Hidrelétrica (UHE) de Tucuruí, estado do Pará. Novos Cadernos NAEA, v. 17, n. 2, p. 167-187, 2014.

BRASIL. Portaria Incra/№ 268, de 23 de outubro de 1996. Dispõe sobre a criação da substituição à modalidade de Projeto de Assentamento Extrativista, a modalidade de Projeto de Assentamento Agroextrativista. Diário Oficial da União, n. 208, seção I, p. 21903, 25 out. 1996.

BUSCHBACHER, R. A Teoria da resiliência e os sistemas socioecológicos: como se preparar para um futuro imprevisível? Boletim regional, urbano e ambiental, n. 9, p. 11-24, 2014.

BUSCHBACHER, R. et al. Resilience Assessment as a tool for understanding the Amazon frontier as a socialecological system. Sustainability in Debate/Sustentabilidade em Debate, v. 7, n. 2, p. 20-35, 2016.

CABELL, J. F.; OELOFSE, M. An indicator framework for assessing agroecosystem resilience. Ecology and Society, v. 17, n. 1, p. 18, 2012.

Holling, C.S. Understanding the complexity of economic, ecological, and social systems.

Ecosystems 2001, 4, 390-405.

Holling, C.S.; Gunderson, L.H. Resilience and adaptive cycles. In Panarchy: Understanding

Transformations in Human and Natural Systems; Gunderson, L.H., Holling, C.S., Eds.; Island

Press: Washington, DC, USA, 2002; pp. 25-62.

CAMPBELL, A. J. et al. Anthropogenic disturbance of tropical forests threatens pollination services to açai palm in the Amazon river delta. Journal of Applied Ecology, p. 1-12, 2017. 
FERREIRA, D. da S. Modo de vida e uso dos Recursos Naturais em uma Comunidade Ribeirinha das Ilhas de Abaetetuba/PA. Terceira Margem Amazônia, v. 1, n. 2, p. 85-106, 2012.

FLEURY, L. C.; MIGUEL, J. C. H.; TADDEI, R. Mudanças climáticas, ciência e sociedade. Sociologias, v. 21, n. 51, p. 18-42, 2019.

FOLKE, C. et al. Regime shifts, resilience, and biodiversity in ecosystem management. Annual Review of Ecology, Evolution, and Systematics, v. 35, p. 557-581, 2004.

FREITAS, G. de; SILVEIRA, S. de F. R. Programa Luz para Todos: uma representação da teoria do programa por meio do modelo lógico. Planejamento e Políticas Públicas, n. 45, p. 177-198, 2015.

FREITAS, M. A. B. et al. Floristic impoverishment of Amazonian floodplain forests managed for açaí fruit production. Forest Ecology and Management, v. 351, p. 20-27, 2015.

GONÇALVES, A. C. O. et al. Belém e Abaetetuba. In: ALVES, F. (Org.). A função socioambiental do patrimônio da União na Amazônia. Brasília: Ipea, 2016.

GONÇALVES, D. de L.; BRASIL, D. do S. B. Problemas ambientais e sustentabilidade nas várzeas da Amazônia Tocantina: um estudo no Projeto de Assentamento Agroextrativista São João Batista II, Abaetetuba, Estado do Pará, Brasil. Revista Pan-Amazônica de Saúde, v. 7, n. 4, p. 89-99, 2016.

GONÇALVES, O. D.; RODRIGUES, J. C.; SOBREIRO FILHO, J. Marés das rebeldias em Abaetetuba: dos rios da existência à resistência dos territórios na Amazônia Paraense, Baixo Tocantins. Revista Tamoios, v. 15, n. 1, p. 80-103, 2019.

HE, Q.; SILLIMAN, B. R. Climate change, human impacts, and coastal ecosystems in the Anthropocene. Current Biology, v. 29, n. 19, p. 1021-1035, 2019.

HIRAOKA, M. Mudanças nos padrões econômicos de uma população ribeirinha do estuário do Amazonas. In: FURTADO, L. G.; LEITÃO, W. M.; MELLO, A. de (Org.). Povos das águas: realidade e perspectivas na Amazônia. Belém: Museu Paraense Emílio Goeldi, 1993.

HOLLING, C. S. Understanding the complexity of economic, ecological, and social systems. Ecosystems, v. 4, n. 5, p. 390-405, 2001.

HOLLING, C. S.; GUNDERSON, L. H. Resilience and adaptive cycles. In: Panarchy: understanding transformations in human and natural systems, p. 25-62, 2002.

INSTITUTO BRASILEIRO DE GEOGRAFIA E ESTATÍSTICA. 2010. Available in: http://www.ibge.gov.br/cidadesat/link. php?codigo=150010\&idtema=1. Access on: 20 abr. 2019.

INSTITUTO DE PESQUISA ECONÔMICA APLICADA. Observatório da Função Socioambiental do Patrimônio da União na Amazônia. Relatório Territorial de Belém e de Abaetetuba. Rio de Janeiro, 2015. Available in: http://www. ipea.gov.br/agencia/images/stories/PDFs/relatoriopesquisa/150714_relatorio_territorial_belem_abaetetuba. pdf. Access on: 1 maio 2016.

INSTITUTO NACIONAL DE COLONIZAÇÃO E REFORMA AGRÁRIA. Informações gerais sobre os assentamentos da Reforma Agrária. Available in: http://painel.incra.gov.br/sistemas/index. php. Access on: 20 abr. 2017.

JARDIM, M. A. G. A cadeia produtiva do açaizeiro para frutos e palmito: implicações ecológicas e socioeconômicas no estado do Pará. Boletim do Museu Paraense Emílio Goeldi, v. 18, n. 2, p. 287-305, 2002. (Série Antropologia).

LIMA, D. M.; POZZOBON, J. Amazônia socioambiental: sustentabilidade ecológica e diversidade social. Estudos Avançados, v. 19, n. 54, p. 45-76, 2005.

LINDOSO, D. P. Vulnerabilidade e resiliência: potenciais, convergências e limitações da pesquisa interdisciplinar. Ambiente \& Sociedade, v. XX, p. 131-148, 2017. 
LIRA, T. de M.; CHAVES, M. do P. S. R. Comunidades ribeirinhas na Amazônia: organização sociocultural e política. Interações, v. 17, n. 1, p. 66-76, 2016.

MACHADO, J. História de Abaetetuba. Edições Alquimia, 2008. 60p.

MARINHO, J. A. M. Desenvolvimento do extrativismo do açaí e mudanças na socioeconomia de ribeirinhos marajoaras. In: GODOI, E. P. de; MENEZES, M. A. de; MARIN, R. A. (Ed.). Diversidade do campesinato: expressões e categorias. Estratégias de reprodução social. São Paulo: Ed. da Unesp, 2009. v. 2, p. 185-210.

MOURÃO, L. História e natureza: do açaí ao palmito. Territórios e Fronteiras, v. 3, n. 2, p. 74-96, 2010.

NAHUM, J. S. De ribeirinha a quilombola: dinâmica territorial de comunidades rurais na Amazônia paraense. CampoTerritório: revista de Geografia Agrária, v. 6, n. 12, p. 79-103, 2011.

NOGUEIRA, O. L. et al. A cultura do açaí. Embrapa-SPI; Belém, PA: Embrapa-CPATU, 1995. 50p.

OSTROM, E. A General Framework for Analyzing Sustainability of Social-Ecological Systems. Science, v. 325, n. 5939, p. 419-422, 2009.

POJO, E. C.; ELIAS, L. D. O cotidiano das águas na tradição quilombola da comunidade do Rio Baixo ItacuruçáAbaetetuba, PA. Tempos Históricos, v. 22, n. 2, p. 49-72, 2018.

QUARESMA, M. et al. Periodização econômica de Abaetetuba (PA) a partir de sua configuração espacial. PerCursos, v. 16, n. 32, p. 143-168, 2015.

ROGEZ, H. Açaí: preparo, composição e melhoramento da conservação. Pará, Universidade Federal do Pará, 2000. 313p.

SALVIA, R.; QUARANTA, G. Adaptivecycle as a tool to select resilient patterns of rural development. Sustainability, v. 7, n. 8, p. 11114-11138, 2015.

SANTANA, A. C. de; PESSOA, J. D. C.; SANTANA. A. L. de. O mercado de açaí e os desafios tecnológicos da Amazônia. In: PESSOA, J. D. C.; TEIXEIRA, G. D. A. Tecnologias para inovação nas cadeias Euterpe. Embrapa Instrumentação - Livros científicos, 2012. 343p.

SANTOS JÚNIOR, H. B. S.; JÚNIOR, W. F. B.; JARDIM, M. A. G. Formas tradicionais no manejo de palmeiras como alternativas de conservação ambiental. Cadernos de Agroecologia, v. 10, n. 3, p. 1-5, 2015.

SILVA, E. S. de A. da; PAES, N. A. Programa Bolsa Família e a redução da mortalidade infantil nos municípios do semiárido brasileiro. Ciência \& Saúde Coletiva, v. 24, p. 623-630, 2019.

SILVA, M. R. O.; PENNINO, M. G.; LOPES, P. F. M. A social-ecological approach to estimate fisher resilience: a case study from Brazil. Ecology and Society, v. 25, n. 1, p. 23, 2020.

TAGORE, M. de P. B. O aumento da demanda do açaí e as alterações sociais, ambientais e econômicas: o caso das várzeas de Abaetetuba, Pará. Dissertação (Mestrado) - Universidade Federal do Pará, Núcleo de Meio Ambiente, Programa de Pós-Graduação em Gestão de Recursos Naturais e Desenvolvimento Local na Amazônia, Belém, 2017. 156p.

TAGORE, M. de P. B.; CANTO, O. do; SOBRINHO, M. V. Políticas públicas e riscos ambientais em áreas de várzea na Amazônia: o caso do Pronaf para produção do açaí. Desenvolvimento e Meio Ambiente, v. 45, p. 194-214, 2018.

TAVARES, G. dos S.; HOMMA, A. K. O. Comercialização do Açaí no estado do Pará: alguns comentários. Observatorio de la economia latinoamerica. Revista Eumed.net. Brasil, Set./2015. Available in: https://www.alice.cnptia. embrapa.br/bitstream/doc/1031486/1/acaipara.pdf. Access on: 10 Sep. 2018.

WALKER, B. H. et al. A handful of heuristics and some propositions for understanding resilience in social-ecological systems. Ecology and Society, v. 11, n. 1, p. 13, 2006. 